\title{
Landfill Leachate Generation and Its Impact on Water at an Urban Landfill (Jebel Chakir, Tunisia)
}

\section{Aydi Abdelwaheb*, Zairi Moncef and Ben Dhia Hamed}

Laboratoire Eau, Energie et Environnement, Ecole Nationale d'Ingénieurs de Sfax, BP: 1173, 3038 Sfax, Tunisia

\begin{abstract}
The current research examined the level of surface and groundwater contamination near a municipal solid waste landfill site in Tunis City. The site of Jebel Chakir is the largest and the first controlled in Tunisia, in operation since May 1999. It receives 1800 tons/day of municipal solid waste incoming from great Tunis. Water quality parameters (physico-chemical and heavy metals) of leachate, surface and groundwater samples were analyzed. The mean concentrations of all measured parameters except Salinity, $\mathrm{Na}_{2} \mathrm{SO}_{4}$ and $\mathrm{Mg}$ in groundwater conform to the stipulated World Health Organization potable water standards and the Tunisian Standard for Drinking Water Quality. The current results show insignificant impact of the landfill operations on surface and the groundwater resource. The existing soil stratigraphy at the landfill site consisting of clay intercalated with clay gypsum or chalky is deduced to have significantly influenced natural attenuation of leachate into the groundwater resource. The research recommends an upgrade of the solous landfill to a standard that would guarantee adequate protection of both the surface and the groundwater resources in the locality.
\end{abstract}

Keywords: Landfill; Leachate; Pollution; Groundwater; Drinking water quality

\section{Introduction}

Although landfill leachates have been proved to be toxic and recalcitrant, landfilling still remains one of the main methods for municipal and industrial solid waste disposal [1]. Leachate is generated as a consequence of rainwater percolation through wastes, chemical biological processes in waste and the inherent water content of wastes themselves [2-4]. Furthermore, landfill leachate generation remains continuous when water comes in contact with the solid waste. The discharge of landfill leachate can lead to serious environmental problems, sinceleachate contains four groups of contaminants: dissolved organic matters; inorganic compounds such as ammonium, calcium, magnesium, sodium, potassium, iron, sulphates, chlorides and heavy metals such as cadmium, chromium, copper, lead, zinc, nickel; and xenophobic organic substances [5]. Contaminants carried in leachate are dependent on solid waste composition and on the simultaneously occurring physical, chemical and biological activities within the landfill [6]. Thus, heavy metals present in leachate can migrate away from the disposal site boundaries and may constitute a serious pollution threat for the water table and the soil around the landfill [7-9]. The impact of landfill leachate on the surface and groundwater has given rise to a number of studies in recent years $[4,8,10]$.

In order to limit and control environmental impact of solid waste, the Tunisian government closed and rehabilitated uncontrolled dumpsites and constructed sanitary landfills similar to the landfill of Jebel Chakir which was the first to be built and also received the domestic waste of Tunis City since May 1999. Leachate generated by the site is kept in 13 storage basins. The leachate storage basins were not lined for prevention of leachate percolation to ground water and soil.

This paper studies the possibility of vertical and lateral percolation of the pollutants by evaluating the impacts on the water of neighbouring sites. Some remedial measures are also suggested to reduce further contamination of water via leachate percolation.

\section{Materials and Methods}

\section{Site description}

The Jebel Chakir is a 31.32 ha landfill site landfill located. The active landfill is situated at about $10 \mathrm{Km}$ southwest of Tunis city and receives the municipal solid wastes produced by the private sector and the four governorates of Tunis, Ariana, Ben Arous and Manouba (Figure 1). It receives on a daily basis, 1800 tons of MSW of which $65 \%$ are organic matter [11]. The high moisture values in MSW contribute to the production of large quantity of leachate.

The soil stratigraphy of Jebel Chakir landfill consists of clay intercalated with clay gypsum or chalky. This lithology is capable of protecting the underlying confined aquifer from leachate contamination. This assertion could not be true of the water table aquifer which has high contamination risk potential [12].

The climate in Tunis City is typically Mediterranean, characterized by dry and warm summers (from June to August), and cool, wet winters (from December to February). The average annual precipitation varies across the Tunis City and much of the precipitation falls in late autumn and early winter where the month of November has the highest precipitation while August has the lowest. The annual precipitation in the city of Tunis is $480 \mathrm{~mm}$. The annual average temperature is $19^{\circ} \mathrm{C}$ (minimum in January with $12^{\circ} \mathrm{C}$ and maximum in August with $27^{\circ} \mathrm{C}$ ), and the average evaporation rate is $129 \mathrm{~mm} / \mathrm{month}$. The annual

*Corresponding author: Aydi Abdelwaheb, Laboratoire Eau, Energie et Environnement, Ecole Nationale d'Ingénieurs de Sfax, BP: 1173, 3038 Sfax, Tunisia, E-mail: abdelwaheb_2000@yahoo.fr

Received January 04, 2012; Accepted March 06, 2012; Published March 10, 2012

Citation: Abdelwaheb A, Moncef Z, Hamed BD (2012) Landfill Leachate Generation and Its Impact on Water at an Urban Landfill (Jebel Chakir, Tunisia). Hydrol Current Res 3:128. doi:10.4172/2157-7587.1000128

Copyright: ( 2012 Abdelwaheb A, et al. This is an open-access article distributed under the terms of the Creative Commons Attribution License, which permits unrestricted use, distribution, and reproduction in any medium, provided the original author and source are credited. 
Citation: Abdelwaheb A, Moncef Z, Hamed BD (2012) Landfill Leachate Generation and Its Impact on Water at an Urban Landfill (Jebel Chakir, Tunisia). Hydrol Current Res 3:128. doi:10.4172/2157-7587.1000128

Page 2 of 5

predominant wind direction is northward. The annual average wind speed (WS) is $5 \mathrm{~m} / \mathrm{s}$.

\section{Leachate generation}

The leachate collection system for the three cells is designed of independent hydraulic systems. The landfill liner system is composed of HDPE geomembrane placed over natural geological foundation. The leachate collection system is composed of a drainage layer of gravel and leachate collection pipes system.

Leachate generation rate for Jebel Chakir landfill has been periodically measured since May 1999. Figure 2 depicted the leachate measured for the period from 1999 to 2007.

For the three cells, the leachate generation is very high in summer period (from June to August). During this period the average of leachate generation is about $80 \mathrm{~m}^{3} /$ day, $100 \mathrm{~m}^{3} /$ day and $130 \mathrm{~m}^{3} /$ day, respectively for cell 1 , cell 2 and cell 3 . This large amount is caused by the large fraction of organic matter and the initial moisture content of waste (water content: $80 \%$ in summer).
The leachate is collected with high density polyethylene pipes (diameter $160 \mathrm{~mm}$ ) and stocked in 13 storage basins of total capacity $130,000 \mathrm{~m}^{3}$ without any treatment (Figure 1). These stocked leachates constitute a real threat to the fauna and flora in surrounding [13]. Tunisian regulations would not allow direct discharge of the leachates neither into a water body nor into the sewer system.

\section{Samples and analysis}

In an effort to investigate the extent of surface and groundwater contamination, three sampling points designated $S 1$ to $S 3$ were selected between 100 and $1000 \mathrm{~m}$ down-gradient of the landfill site while the leachate sample was designated L. Leachate samples were collected from $1 \mathrm{~m}$ depth at the storage basins (Figure 1). Groundwater sample (S1) was collected from well in the vicinity of the landfill (the single well around the landfill of Jebel Chakir) while surface water (S2 and S3) samples were collected from Oued El Jazzar (Figure 3). Field sampling was done only at the end of the wet season (December, 2006), due to the high precipitation during this month.

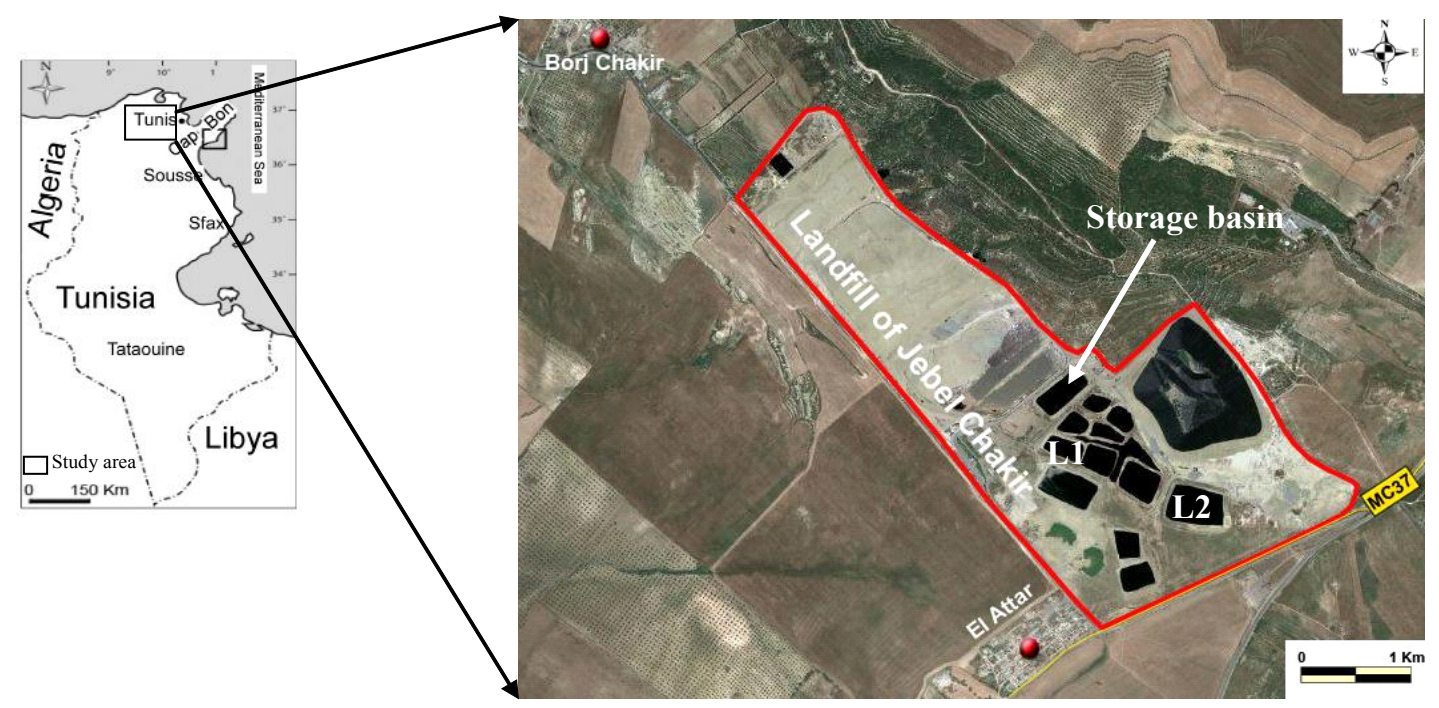

Figure 1: Landfill Jebel Chakir map with 13 basins of leachate storage (Google earth, 2011).

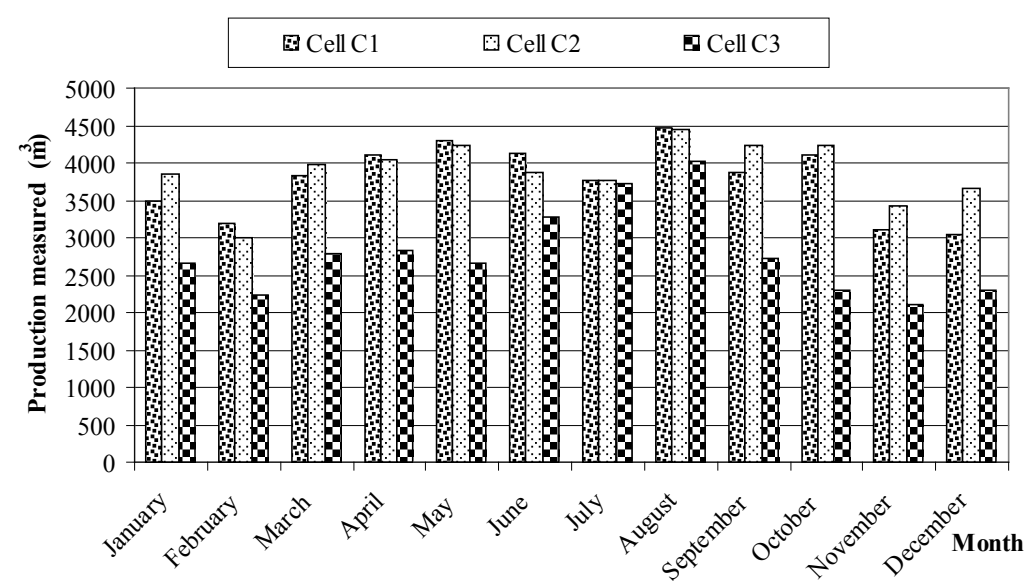

Figure 2: Leachate generation in the three cells at the landfill of Jebel Chakir (1999-2007). 
Citation: Abdelwaheb A, Moncef Z, Hamed BD (2012) Landfill Leachate Generation and Its Impact on Water at an Urban Landfill (Jebel Chakir, Tunisia). Hydrol Current Res 3:128. doi:10.4172/2157-7587.1000128

Page 3 of 5

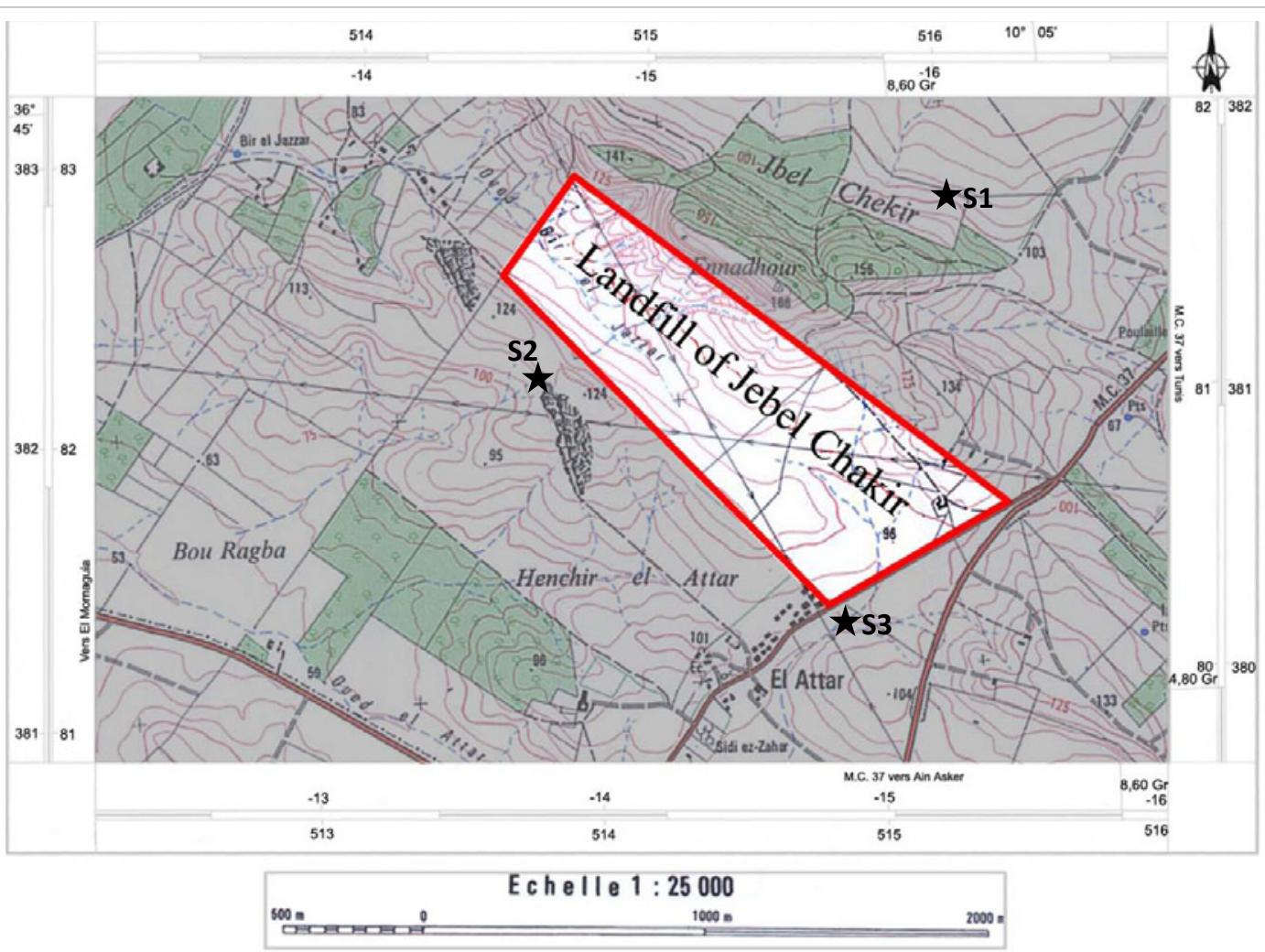

Figure 3: Map of Jebel Chakir landfill and position of the water sampling sites.

Details of the sampling points are presented in Table 1.

Water samples were collected in 1litre plastic containers and prior to collection as part of our quality control measures all the bottles were washed with non-ionic detergent and rinsed with de-ionized water prior to usage. Before the final water sampling was done, the bottles were rinsed three times with well water at the point of collection. Each bottle was labelled according to sampling location while all the samples were preserved at $4^{\circ} \mathrm{C}$ in the laboratory until used.

The electrical conductivity (EC), the salinity and $\mathrm{pH}$ were measured in situ by using a multi-parameter conductimeter (WTW Windaus LF 538) and a pH meter (WTW Windaus pH 538 with combine electrode).

The concentration in sodium $(\mathrm{Na})$, chloride $(\mathrm{Cl})$, sulfate $\left(\mathrm{SO}_{4}\right)$ and magnesium $(\mathrm{Mg})$ were determined by NFT 90-003 AFNOR methods (1999) [14]. COD was measured following the MA-315 COD-1.0 [15].

The biochemical oxygen demand $\left(\mathrm{BOD}_{5}\right)$ was measured by using a BOD meter. The total nitrogen was determined using (NT) titremetric method EN 25663. The heavy metals ( $\mathrm{Fe}, \mathrm{Cr}, \mathrm{Zn}, \mathrm{Cu}, \mathrm{Cd}, \mathrm{Ni}, \mathrm{Pb}$, and $\mathrm{Mn}$ ) were estimated by digestion in $\mathrm{HF}-\mathrm{NO}_{3}-\mathrm{HCLO}_{4}$, and the concentrations of these elements in digestion solution were determined using an Atomic Absorption Spectrometer Perkin-Elmer Analyst 200.

\section{Results and Discussions}

\section{Qualitative characterisation of leachate}

The data in Table 2 summarises the analyses of leachate used in this work. It is alkaline mixture of dark colour.

The eclectic conductivity of leachate ranges from 36.5 to $42.8 \mathrm{~ms} /$ $\mathrm{cm}$, which is higher than the domestic waste water and twice higher than the ones typically reported in literature [16]. This parameter shows the high minerals contents.

BOD consists of biologically degradable dissolved organics in the leachate. COD is a measure of chemically oxizdable components in leachate and reflects the amount of $\mathrm{O}_{2}$ that is required by the bacteria to metabolize the existing organic substrate as well as the $\mathrm{O}_{2}$ required by other oxidizable chemical compounds.

The $\mathrm{COD}$ and the $\mathrm{BOD}_{5}$ values of two samples are much higher than the Tunisian regulation values for discharge in public sewer.

The leachate originating from the Jebel Chakir landfill has very high organic matter content (COD) is $21480 \mathrm{mg} \mathrm{O}_{2} / 1$ on average while its $\mathrm{BOD}_{5}$ is weak ( $5490 \mathrm{mg} \mathrm{O}_{2} / \mathrm{l}$ on average). The ratio $\mathrm{BOD}_{5}$ to COD indicates the degree of biodegradability of the leachate and provides indications regarding the age of a landfill and about biochemical alterations within the landfill [4]. It was 0.25 for the two samples, corresponding to the intermediate stage of leachate evolution. This reveals that the leachates are in the reactional step of anaerobic degradation.

The average concentrations of heavy metals: $\mathrm{Cr}, \mathrm{Zn}, \mathrm{Cu}, \mathrm{Cd}, \mathrm{Pb}$, $\mathrm{Ni}$ and $\mathrm{Mn}$ are well below the Tunisian regulations for discharge in a

\begin{tabular}{|c|c|c|}
\hline Sample & Sample Location & Depth to water level in wells \\
\hline L1 & Storage basin B5 (1m depth) & - \\
\hline L2 & Storage basin B8 (1m depth) & - \\
\hline S1 & $1000 \mathrm{~m}$ from landfill & - \\
\hline S2 & $150 \mathrm{~m}$ from landfill & - \\
\hline S3 & $100 \mathrm{~m}$ from landfill & -0 \\
\hline
\end{tabular}

Table 1: Sampling Location. 
Citation: Abdelwaheb A, Moncef Z, Hamed BD (2012) Landfill Leachate Generation and Its Impact on Water at an Urban Landfill (Jebel Chakir, Tunisia). Hydrol Current Res 3:128. doi:10.4172/2157-7587.1000128

Page 4 of 5

\begin{tabular}{|c|c|c|c|c|}
\hline Parameters & L1 & L2 & Mean (L1 \& L2) & NT $106002^{* *}$ \\
\hline $\mathrm{pH}$ & 8.25 & 8.15 & 8.20 & $6.5-9$ \\
\hline Electric conductivity $(\mathrm{ms} / \mathrm{cm})$ & 42.80 & 36.50 & 39.65 & NA \\
\hline $\operatorname{COD}\left(\mathrm{mg} \mathrm{O}_{2} / \mathrm{l}\right)$ & 20500 & 22460 & 21480 & 1000 \\
\hline BOD5 $\left(\mathrm{mg} \mathrm{O}_{2} / \mathrm{l}\right)$ & 5780 & 5200 & 5490 & 400 \\
\hline BOD5/COD & 0.28 & 0.23 & 0.25 & 0.4 \\
\hline $\mathrm{Fe}(\mathrm{mg} / \mathrm{l})$ & 20500 & 22460 & 21480 & 5 \\
\hline $\mathrm{Cr}(\mathrm{mg} / \mathrm{l})$ & 1.22 & 1.12 & 1.17 & 0.5 \\
\hline $\mathrm{Zn}(\mathrm{mg} / \mathrm{l})$ & 0.72 & 0.77 & 0.745 & 5 \\
\hline $\mathrm{Cu}(\mathrm{mg} / \mathrm{l})$ & 0.81 & 0.78 & 0.795 & 1 \\
\hline $\mathrm{Cd}(\mathrm{mg} / \mathrm{l})$ & 0.042 & 0.047 & 0.044 & 0.1 \\
\hline $\mathrm{Ni}(\mathrm{mg} / \mathrm{l})$ & 0.22 & 0.25 & 0.23 & 2 \\
\hline $\mathrm{Pb}(\mathrm{mg} / \mathrm{l})$ & 0.4 & 0.3 & 0.35 & 1 \\
\hline $\mathrm{Mn}(\mathrm{mg} / \mathrm{l})$ & 0.048 & 0.051 & 0.046 & 1 \\
\hline
\end{tabular}

** Norm for the wastewater drained to public sewer, Tunisia

NA: Not available

Table 2: Physical and biochemical of Jebel Chakir leachate landfill site.

\begin{tabular}{|c|c|c|c|c|c|}
\hline \multirow{3}{*}{ Chemical parameters } & \multicolumn{3}{|c|}{ Samples } & \multirow{3}{*}{$\begin{array}{l}\text { Tunisian Standard } \\
(\text { NT } 106002)^{* *}\end{array}$} & \multirow{3}{*}{$\begin{array}{c}\text { WHO standards } \\
{[19]}\end{array}$} \\
\hline & \multirow{2}{*}{$\begin{array}{c}\text { Groundwater sample } \\
\text { (S1) }\end{array}$} & \multicolumn{2}{|c|}{ Rivers of Oued Bir El Jazzar } & & \\
\hline & & (S2) & (S3) & & \\
\hline $\mathrm{pH}$ & 7,9 & 7,6 & 7,8 & $6.5<\mathrm{pH}<8.5$ & $6.5-9.2$ \\
\hline $\mathrm{BOD}(\mathrm{mg} \mathrm{O} / \mathrm{l})$ & 25 & 20 & 22 & 30 & -- \\
\hline $\mathrm{COD}(\mathrm{mg} \mathrm{O} / \mathrm{l})$ & 80 & 60 & 65 & 90 & -- \\
\hline Salinity (mg/l) & 4900 & 1800 & 1900 & -- & 1200 \\
\hline $\mathrm{Na}(\mathrm{mg} / \mathrm{l})$ & 949.9 & 190 & 200 & 300 & 200 \\
\hline Nitrogen (mg/l) & 4 & 2 & 1 & 1 & 1.5 \\
\hline Chloride (mg/l) & 1402 & 80 & 55 & 600 & 250 \\
\hline $\mathrm{Mg}(\mathrm{mg} / \mathrm{l})$ & 180 & 40 & 50 & 200 & 30 \\
\hline $\mathrm{SO}_{4}(\mathrm{mg} / \mathrm{l})$ & 580 & 130 & 100 & 600 & 250 \\
\hline $\mathrm{Cd}(\mathrm{mg} / \mathrm{l})$ & 0.05 & ND & 0.005 & 0.005 & 0.01 \\
\hline $\mathrm{Zn}(\mathrm{mg} / \mathrm{l})$ & 0.30 & 0.15 & 0.2 & 5 & 5.0 \\
\hline $\mathrm{Cu}(\mathrm{mg} / \mathrm{l})$ & 0.45 & 0.25 & 0.3 & 0.5 & 1.0 \\
\hline
\end{tabular}

** Norm for the wastewater drained to public water body, Tunisia

ND: not detected

Table 3: Chemical analysis of water samples collected around the landfill of Jebel Chakir.

public sewer. But the iron and the chromium exceed the limits set by Tunisian regulations.

The heavy metals in the leachate samples from landfill of Jebel Chakir show a typical composition compared to urban landfill leachates reported by Christensen et al. [17]. The relatively low concentration of analyzed heavy metals and the high BOD, COD and nitrogen concentration confirm the high organics content of the waste deposited in the landfill of Jebel Chakir [9].

As compared to leachates to European norm from controlled landfills, the effluents of Jebel Chakir landfill appear much less loaded in mineral pollutants but more in organic materials [18].

\section{Evaluation of the pollution potential caused by the landfill leachate}

In order to detect any potential pollution from the landfill to the surroundings, samples of surface and ground water from wells were collected and were analysed to the same parameters as in leachate samples (Figure 3).

The results of chemical analyses conducted on these water samples are presented in Table 3.

The results of $\mathrm{pH}$ measurement indicate neutral waters at the three samples. A low salinity is observed in the samples collected from the rivers of Oued El Jazzar: $1.85 \mathrm{~g} / \mathrm{l}$. A low concentration of chloride, sulphate, and magnesium is denoted in the samples S2 and S3.

A high salinity of $4.9 \mathrm{~g} / \mathrm{l}$ is found in the groundwater samples. Salinity in surface and groundwater are not within the standard acceptable levels for drinking water by WHO [19].

This elevated value is probably caused by the salt in the PlioceneQuaternary clay-sandy deposits and high evaporation in this zone [20]. Chloride, sulphate, and magnesium concentrations are high in the groundwater samples, which confirmed that the groundwater water is not drinkable.

The analytical results of chemical parameters for three water samples indicate the water quality satisfy the Tunisian regulation (NT 106 002). In addition, the heavy metals in the three water samples present a low value. It is clear that water analysed in the vicinity area of Jebel Chakir landfill are not affected by leachate percolation.

The lateral and vertical migration of pollutants is probably limited within the landfill of Jebel Chakir. Thus, clayey layers at the base of storage basin are acting as barrier against the lateral and vertical migration of pollutants towards the surrounding environment of the landfill. However, this aspect needs further investigations by drillings 
Citation: Abdelwaheb A, Moncef Z, Hamed BD (2012) Landfill Leachate Generation and Its Impact on Water at an Urban Landfill (Jebel Chakir, Tunisia). Hydrol Current Res 3:128. doi:10.4172/2157-7587.1000128

Page 5 of 5

wells of varying distance and depth for assessing potential pollution of water in time.

\section{Conclusion}

Landfill from the sanitary landfill of Jebel Chakir is most likely in methanogenic phase in which $\mathrm{pH}$ was 8.20 . The BOD5/COD ratio (0.25) indicates that the two different leachates are old and stable. Most of parameters in Jebel Chakir landfill leachate exceed the permissible required for treated wastewater discharge determined by local standard. The concentrations of heavy metals in Jebel Chakir are above the standard acceptable levels of treated wastewater discharge determined by the local standard.

The results obtained in this study shows that the leachate generated from the landfill site has a minimal impact on the surface and groundwater quality in the locality. The soil stratigraphy of the site, being predominantly clay intercalated with clay gypsum or chalky, seems to have significantly influenced the low levels or absence of contaminants especially heavy metals in the groundwater samples.

\section{References}

1. Lopez A, Pagano M, Volpe A, Di Pinto AC (2004) Fenton's pre-treatment of mature landfill leachate. Chemosphere 54: 1005-1010.

2. Debra RR, Caroline JG (1998) Analysis of Florida MSW Landfill Leachate Quality. 108p.

3. Tazi H (2001) Déchets solides: Etude d'impact sur l'Environnement (sol, eaux souterraines) et traitement par voie de compostage. Thesis, University El Jadida, Morocco : 224

4. Chofqi A, Younsi A, Lhadi EK, Mania J, Mudry J, et al. (2004) Environmental impact of an urban landfill on a coastal aquifer (EI Jadida, Morocco). J Afr Earth Sci 39: 509-516.

5. Kjeldsen P, Barlaz MA, Rooker AP, Baun A, Ledin A, et al. (2002) Present and long-term composition of msw landfill leachate: a review. Critical Reviews in Environmental Science and Technology 32: 297-336.

6. Adeyemi O, Oloyede OB, Oladiji AT (2007) Effect of leachate-contaminated groundwater on the growth and blood of albino of rats. The Internet Journal of Hematology 3: 1-6.

7. Matejka G, Rinke M (1999) Mineral Pollutant Migration in soil under a Domestic
Waste Landfill. Seventh International Waste Management and Landfill Symposium Cagliari, Italy.

8. Yoshida M, Sothom A, Souissi N, Bousselmi L, Jedidi N, et al. (2002) Characterization of leachate from Henchir El Yahoudia closed landfill. Solid Waste and Soil/sediment contamination: case Studies in Tunisia: 1-9.

9. Zairi M, Ferchichi M, Ismail A, Jenayeh M, Hammami H (2004) Rehabilitation of El Yahoudia dumping site, Tunisia. Waste Management 24: 1023-1034.

10. Marzougui A, Ben Mammou A (2006) Impacts of the dumping on the environment: case of the Henchir El Yahoudia Site, Tunis, Tunisia. C R Geosciences 338: 1176-1183.

11. Aydi A, Zairi M, Kallel A, Ben Dhia H (2009) Caractérisation de la décharge contrôlée de Jebel Chakir-Tunis, Tunisie. Techniques Sciences et Méthodes $5: 101-112$.

12. Bouzayani B (2007) Etude de la diffusion de la pollution par le lixiviat de la décharge de Jebel Chakir avec l'utilisation des Systèmes d'Informations Géographiques (SIG). Mémoire de mastère, Institut Supérieur des Sciences Biologiques Appliquées à Tunis (ISSBA).

13. Tizaoui C, Bouselmi L, Mansouri L, Ghrabi A (2007) Landfill leachate treatment with ozone and ozone/hydrogen peroxide systems. J Hazard Mater 140: 316324

14. AFNOR (1999) La qualité de l'eau: Tome 2 analyses organoleptiques, mesures physico-chimiques, paramètres globaux, composés organiques.

15. Centre d'expertise en analyse environnementale du QUEBEC (2003) Détermination de la demande chimique en oxygène dans les effluents:MA.315DCO1.0, Ministère de l'environnement du Québec, 14

16. Blight GE, Fourrie AB, Shamrock J, Mbande C, Morris JWF (1999) The effect of waste composition on leacahte and gas quality: a study in South Africa. Waste Manage Res 17: 124-140.

17. Christensen TH, Kjeldsen P, Bjerg PL, Jensen DL, Christensen JB, et al. (2001) Biogeochemistry of landfill leachate plumes. Appl Geochem 16: 659-718.

18. ADEME (1996) Guide méthodologique pour la remise en état des décharges d'ordures ménagères et assimilées. Agence de l'Environnement et de la Maîtrise de l'Energie, France.

19. WHO (2004) World Health Organisation. Guidelines for drinking water quality Geneva.

20. Tounsi M (2006) Evaluation environnementale de la station d'épuration de Tunis Ouest-El Attar, rapport : 135. 